\title{
A CASE OF ECONOMICAL DAMAGE DONE BY NEBALIA
}

AUTHOR(S):

Nishimura, Saburo; Hamabe, Mototsugu

CITATION:

Nishimura, Saburo ...[et al]. A CASE OF ECONOMICAL DAMAGE DONE BY NEBALIA. PUBLICATIONS OF THE SETO MARINE BIOLOGICAL LABORATORY 1964, 12(2): 173-175

\section{ISSUE DATE:}

1964-10-15

URL:

http://hdl.handle.net/2433/175356

RIGHT: 


\title{
A CASE OF ECONOMICAL DAMAGE DONE BY NEBALIA
}

\author{
SABURo NISHIMURA \\ Seto Marine Biological Laboratory, Sirahama \\ and \\ Mototsugu HAMABE \\ Kasumi Branch of the Japan Sea Regional Fisheries \\ Research Laboratory, Kasumi, Hyogo-Ken
}

With 2 Text-figures

It is generally known that typical nebalians, i.e. members of the genera Nebalia and Nebaliella, are filter-feeders upon detritus; they live on the muddy bottom and feed, it is supposed, on small organic particles suspended just above the mud or take coarser particles in by filtrating them rapidly before they settle as the animals burrow or kick up the mud (RoweTT 1943). Recently the authors happened to learn an interesting case of feeding habit of this peculiar crustacean, which has been, so far as the present authors are concerned, never recorded in the Japanese waters and seems to suggest that the animal may affect to some extent the natural economy in the sea under special circumstances.

In the early summer of 1957, the junior author was engaged in gathering specimens of the sharp-nosed shark, Scoliodon walbeehmi (BLEEKER), caught by long line in the waters around the Oki Islands in the southern Japan Sea for the purpose of investigating their stomach contents; and then his attention was called on the frequent occurrences of not a few individuals more or less heavily damaged among the fished sharks. These damaged sharks showed a common symptom that the muscles had variously been scraped off and lost so that the skin had been detached for the most part of the body from the underlying muscle layers, leaving spacious hollows between the skin and the skeleton. And in these hollows were found numerous little crustaceans attaching to or encroaching, it was supposed, into muscles. The frequency of occurrence and the degree of damage done by this little animal varied with circumstances. When the long lines were kept sunk for two or three days longer on

1) Contributions from the Seto Marine Biological Laboratory, No. 418.

Publ. Seto Mar. Biol. Lab., XII (2), 1964. (Article 14) 
account of rough weather, then more damaged sharks were met with and the degree of damage was more intensive. In an extreme instance, all musculature and other soft parts of the shark body were almost completely robbed off and there were left only skin and skeleton.

The offensive behavior of this crustacean upon the fishes caught by fishing gears was first reported by the junior author in a short article in Japanese with the title "On the uso" (Hamabe 1958). Uso is the local name for this little crustacean talked among the fishermen of the Oki Islands. In this article appeared in a publication of limited circulation, the junior author presented a sketch of the crustacean, which is here reproduced in Text-fig. 1, but erroneously referred the animal to a species of amphipods. The senior author, examining some specimens sent to him from the junior author, confirmed that the crustacean was a species of the genus Nebalia LEACH, 1814.

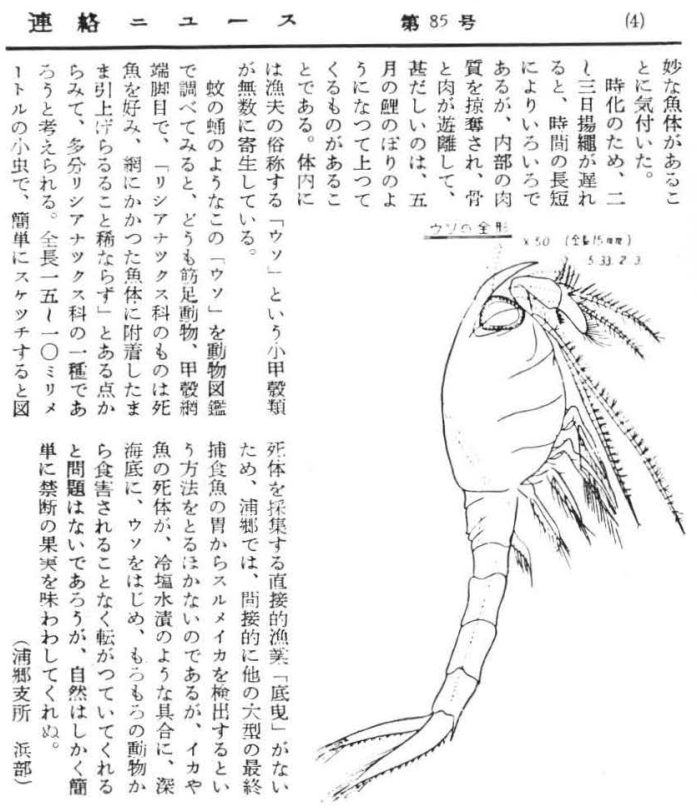

Text-fig. 1. The sketch of "uso" given by the junior author in his 1958 paper, together with part of the explanation.

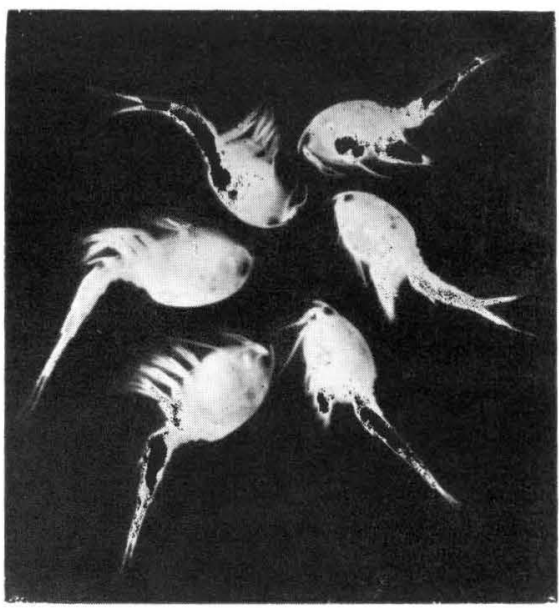

Text-fig. 2. Nebalia sp. taken from an affected sharp-nosed shark.

$\mathrm{x} 2.5$

Dissecting the nebalians (Text-fig. 2) collected from a damaged sharpnosed shark, the senior author noted that, though some individuals had ingested bottom deposits containing many siliceous particles imbedded in debris matrix, others had the intestine packed with a matter referrable to masticated animal tissues together with a rich oily substance. It seems that certain nebalians had actually been feeding on the muscles and other soft parts, such as liver, 
of the shark*, while the specimens containing only bottom deposits in the intestine but no trace of animal tissues might be the individuals arrived at that shark just before it was taken out of the water.

A part of the specimens of Nebalia were sent to Dr. Masao IwAsa of the Seikei University, Tokyo, for specific identification.

The fact that nebalians swarm to rotten animal substance such as dead crabs or shrimps on the sea bottom was already noticed by RoBINson (1906; cited by Komai 1917), but yet there has been no report mentioning that the animals attack and devour the fish caught by fishing gears as certain species of necrophagous isopods and amphipods do. The latter crustaceans have been well known among Japanese coastal fishermen as loathsome pests to their catch. It may be surprising to see that in certain localities at least nebalians are distributed so densely as to swarm enormously to and devour such largesized dead animals as sharks till these are finally disintegrated in a rather short time. In these localities, the role of nebalians as scavengers in the sea must be re-evaluated.

Before closing this short note, the authors express their sincere gratitude to Dr. Takasi Tokioka of the Seto Marine Biological Laboratory who kindly read the manuscript.

\section{REFERENCES}

Hamabe, M. 1958. [On the uso]. Nihonkai-ku Suisan Shiken Kenkyû Renraku Nyûsu, No. 85, pp. 3-4. (In Japanese.)

KomaI, T. 1917. [Nebaliacea]. Dobutsugaku Zasshi, Vol. 29, pp. 297-298. (In Japanese.)

Rowet, H. G. Q. 1943. The gut of Nebaliacea. Discovery Repts., Vol. 23, pp. 3-17.

* The sharp-nosed shark contains an exceptionally large amount of oil in the liver, and this shark was once fished in a great scale around the Oki Islands for the purpose of gathering liver oil and extracting vitamin A from it. 